\title{
Innovation and supervision of rural Internet Finance
}

\author{
Fu Linna ${ }^{1}$ \\ ${ }^{1}$ Liaoning Financial Vocational College,Liaoning,Shenyang 110122
}

\begin{abstract}
Internet finance has become an important support for the development of rural economy in China, and its business field and scope continue to expand. In the process of rapid development of rural Internet finance, it not only brings new opportunities for rural economic development, but also brings new challenges to rural economic stability. From the perspective of promoting the sustainable and healthy development of rural Internet finance, this paper analyzes the current situation and risks of China's rural Internet finance innovation and development, and puts forward measures and Countermeasures to strengthen supervision and reduce risks.
\end{abstract}

\section{Introduction}

China is a big agricultural country, about $40 \%$ of the 1.4 billion people are farmers. As of December 2019, there are 55.162 million permanent rural residents. Rural areas are the weak areas of China's financial services. Rural financial reform and development is one of the key tasks of the party and the government since the reform and opening up, and occupy an important position in China's economic development and financial field. Rural financial reform has gradually entered the deep water area. The entities of rural economy such as rural credit cooperatives and other financial entities that provide financial services by means of business outlets can not meet the needs of rural economy scattered in the region and the vast area. The development mode of Internet plus rural finance has attracted widespread attention in the society due to its low cost, high efficiency and low threshold. With the help of Internet technology, the spatial gap of rural finance can be solved, which is helpful to achieve targeted poverty alleviation and accelerate the promotion of rural Inclusive Finance.

\section{Current situation of rural Internet Finance Development}

\subsection{Overall development of rural Internet}

\subsubsection{The scale of rural Internet users and Internet penetration rate}

As of June 2020, the number of rural Internet users in China has reached 285 million, accounting for $30.4 \%$ of the total number of Internet users (see Figure 1). The scale is amazing and shows a trend of continuous increase. The structure of Internet users in urban and rural areas has been gradually optimized. The gap between rural network technology level and urban network technology is getting smaller and smaller. The era of "same network and same speed" between rural and urban areas is coming. The Internet penetration rate in rural areas of China has reached $52.3 \%$ (see Figure 2). With the strong support of relevant national policies, the network poverty alleviation has achieved remarkable results, especially in 2020, affected by the epidemic situation, the rural Internet penetration rate has increased significantly, making a historic breakthrough. With the continuous promotion of "broadband China" strategy, more and more rural residents will enjoy the services brought by the Internet. The increasing popularity of Internet in rural areas will contribute to the scale development of rural Internet finance.

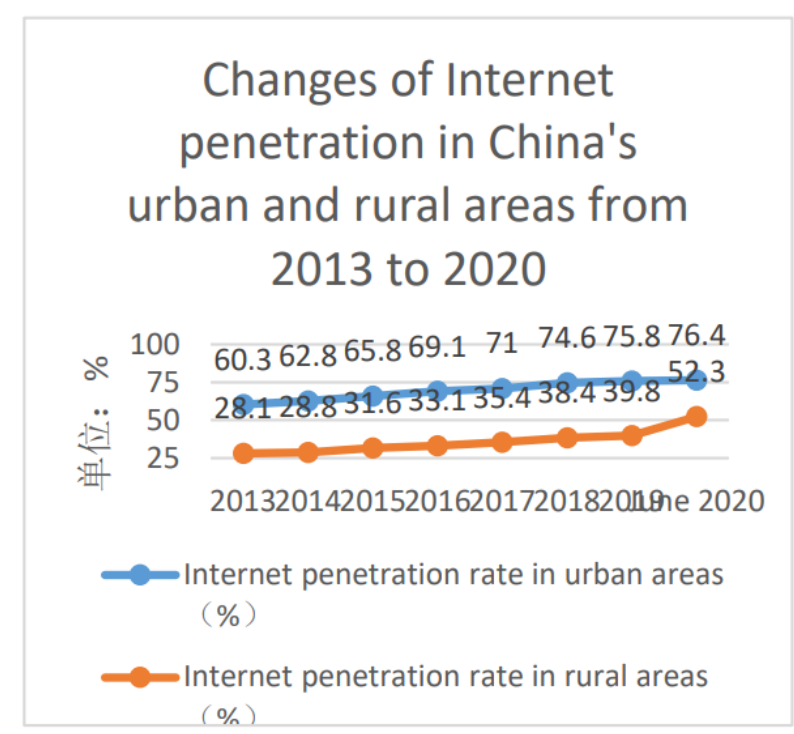

Figure 1 Distribution of Internet users in urban and rural areas of China from 2018 to June 2020(source: CNNIC) 


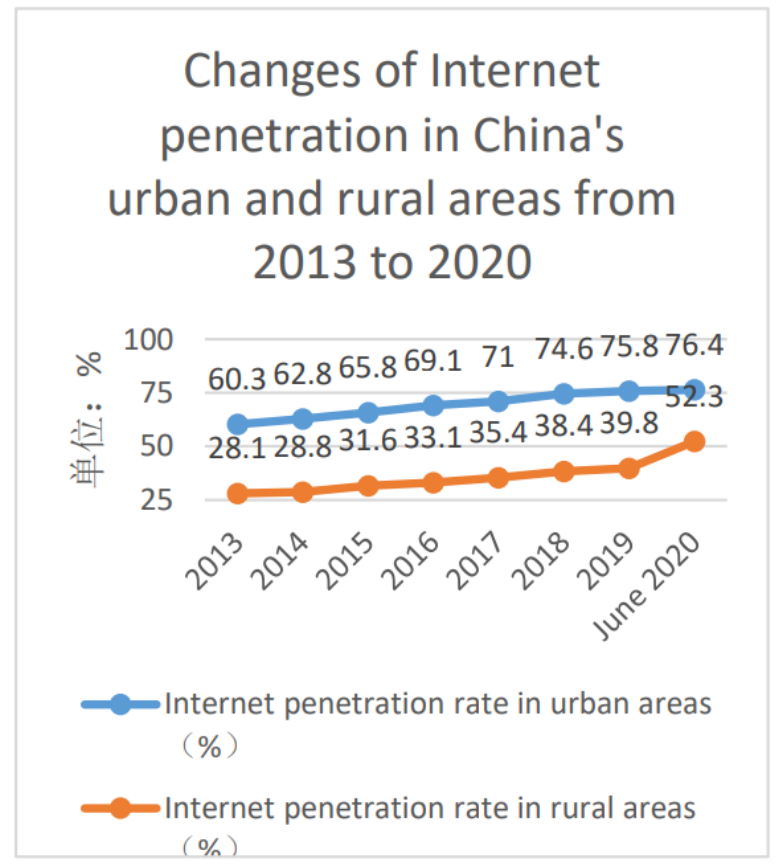

Figure 2 Changes of Internet penetration in China's urban and rural areas from 2018 to June 2020(source: CNNIC)

\subsubsection{Rural Internet business development is fast in the context of "Internet plus"}

The foundation of "Internet plus" agriculture is to rely on the Internet's communication and information processing technology and procedures to transfer the agricultural positions which rely mainly on "offline" production and operation to the Internet. The production, sales, supply and other links in rural areas will be fully covered through the network platform, and at the same time, the whole process of e-commerce services such as information, transaction, settlement and transportation will be provided for the rural areas. E-commerce and agricultural products are highly integrated. With the help of rural e-commerce platform, the operation mode of consumers' online shopping, online transaction between merchants and online payment is realized. With the help of the Internet, it breaks the spacetime restrictions of market transactions, saves operating costs and effectively promotes the development of "agriculture, rural areas and farmers". In recent years, China's rural e-commerce industry has developed rapidly. It is expected that by the end of 2020 , the scale of rural ecommerce transactions in China will break through the 3 trillion mark. The mainstream platforms of rural ecommerce market mainly include the following categories:

Table 1 rural e-commerce platform

\begin{tabular}{|c|c|}
\hline $\begin{array}{c}\text { E-commerce mainstream } \\
\text { platform }\end{array}$ & Representative Enterprises \\
\hline $\begin{array}{c}\text { Integrated platform e- } \\
\text { commerce }\end{array}$ & Alibaba, Jingdong, Pinduoduo , Suning E-commerce \\
\hline $\begin{array}{c}\text { E-commerce of agricultural } \\
\text { products }\end{array}$ & Shopping website, Chain farming, Delicious food \\
\hline Network brand e-commerce & Three squirrels, Baicaowei and Xinnongge \\
\hline Fresh e-commerce & Small farmer girl, Shunfeng preferred, COFCO i-buy.com \\
\hline
\end{tabular}

\subsection{The operation mode of rural Internet Finance in China}

Rural Internet finance has the characteristics of low cost, high efficiency and cross regional. Based on the services provided by the network platform, the combination of online and offline is the specific application of Internet Finance in the rural financial field. It carries out financial services around rural areas, farmers and agriculture. Internet finance uses big data to embed into rural economy, and uses Internet credit technology to improve social performance On the idle funds for redistribution. Starting from the connotation of China's rural Internet finance, relevant scholars have studied the current rural Internet financial platform, and from the asset side and capital side, summed up four operation modes of rural Internet Finance in China: franchisee mode, supply chain finance mode, self financing lending mode and land mortgage mode. Among them, franchisee mode and self financing lending mode are the two main modes of rural Internet financial operation in China.

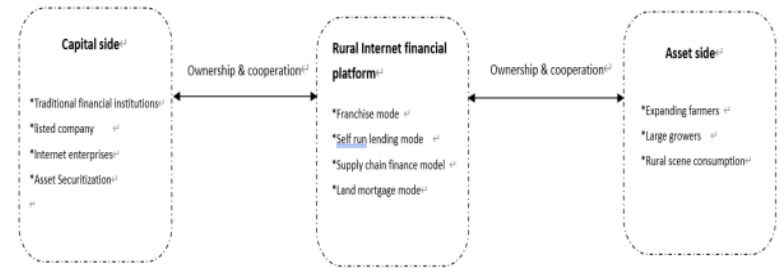

Figure 3 operation mode of rural Internet Finance

\subsection{The development status of Internet Finance in China's rural areas}

With the rise of Internet financial services represented by P2P network loan platform in China, Internet finance has become a new force in the financial field. Driven by the demand of financial market, Internet finance has sprung up like mushrooms. E-commerce giants led by Alibaba and Jingdong have distributed ant financial services and Jingdong financial services to rural areas, and have successively launched innovative products to meet rural financial needs. Ali's vision of Alipay going to the countryside is "the people's Bank of the mountains and waters". The mission is to "get through the last 100 meters of rural finance", and provide comprehensive financial services such as small and micro loans, insurance and 
financial management for the rural areas, so as to realize inclusive finance going to the countryside.

With the increase of the scale of rural Internet users and Internet penetration rate year by year, Internet finance has broadened the financing channels in rural areas and provided efficient and efficient financial services for rural economy. Relevant micro financial enterprises, bank financial institutions and non-bank financial institutions form a wide coverage and multi-level rural financial service system. With the help of Internet financial platform, loan, consumption, payment, crowdfunding, insurance and other businesses emerge in an endless stream, which meets the financial needs of rural residents and makes up for the service defects of traditional rural financial institutions. As a new type of business, rural Internet finance also has certain risks. In recent years, a large number of rural Internet financial institutions have closed down. In addition to building a sound rural credit reporting system, relevant regulatory departments should increase the penetrating supervision of rural Internet Finance and innovate supervision countermeasures, so as to promote the sustainable and healthy development of rural Internet finance.

\section{Risks of rural Internet Finance}

The essence of rural Internet finance is finance, but the regions and service objects are different, and the risks faced by them are also different.

\subsection{Technical risks of rural Internet Finance}

(1) Network security risk. The handling and operation of rural Internet financial business is based on the network platform. While simplifying the business handling procedures and processes, it also puts forward higher requirements for the stability and technical security of the network. Once the technical failure or loophole occurs in the network, the security risk of the entire financial system will be generated, and there is the possibility of significant economic loss.

(2) Information risk. Under the background of Internet finance, customer information and credit information depend on the storage and application of electronic database. There are also problems of information leakage, data loss and data tampering, which will seriously affect the operation of rural Internet Finance and cause fatal losses. At the same time, the rural Internet financial operation is to change the business mode from offline to online. The information collection of credit process, risk assessment, credit fund issuance, post loan management and loan recovery should use Internet information system. All kinds of information will inevitably have problems exposed due to technical reasons.

Infrastructure risk. Compared with the city, most of the rural areas in China have relatively single and lagging Internet financial equipment and facilities, which leads to the risk of infrastructure failure in the development of rural Internet finance.

\subsection{Business risks of rural Internet Finance}

Credit risk. On the one hand, the operation of rural Internet finance needs to rely on big data analysis and technology as support, which has replaced the asset mortgage credit mode of traditional finance to a certain extent. However, compared with the cities with higher population concentration and more convenient access to information, the information flow of rural economic entities is weak and difficult to obtain. In the process of Internet financial operation, the implicit guarantee function of big data is sometimes insufficient, resulting in credit risk. More importantly, most of the rural areas in China have not established a perfect credit system, and there are certain threshold restrictions on the use of some credit system, which requires higher fees. On the other hand, the service object of rural Internet finance is mainly rural residents, and its operation advantage lies in the lower financing threshold, while the operation of rural industry has the characteristics of greater risk. The rural business entities with incomplete credit information and lack of collateral tend to use the Internet for financing, which correspondingly increases the credit risk of rural Internet finance.

(2) Operational risk. Rural Internet Finance operators, many from the local grassroots financial business personnel, they are particularly familiar with the traditional credit environment, the basic situation of the rural business entities in the region is also very familiar, but due to the overall level of education and low acceptance of information technology application, in the process of business operation, the operational risk of rural Internet finance is increased Big. At the same time, compared with the traditional bank financial institutions, the offline facilities and staffing of rural Internet financial operation are relatively insufficient, the operation network system and information technology application are not professional, and there is a lack of supervision in the process of risk control, which is easy to cause subjective errors of operators and cause operational risks.

\subsection{Legal and policy risks of rural Internet Finance}

(1) Legal risk. First, the laws and regulations of rural Internet financial supervision are not perfect. First of all, the regulatory body is not clear enough. The supervision of rural Internet finance involves both technology companies and rural financial institutions. There are business overlapping between the two, and the unclear regulatory body is easy to lead to difficulties in the implementation of supervision and management measures. Second, the rural Internet financial business is a relatively new business model, the introduction of relevant laws and regulations has a certain lag, and the laws related to information security, business market access, customer protection and other aspects are not perfect, which is easy to generate risks in the operation.

( 2 ) Policy risk. First, the supervision and management mechanism of rural Internet finance is not perfect. In the case of various Internet financial business 
models, once the financial transaction subject has legal disputes, its supervision and management can not be effectively implemented. Second, the mixed operation of rural Internet finance is different from the separate operation of traditional finance. The government's supervision lags behind, which makes the operation and development of rural Internet Finance blind, and the competition is disordered, resulting in the risk of nonstandard operation. The third is the risk of policy change. The introduction of national policies is of a global and strategic nature. Once it has an adverse impact on the main body of rural Internet finance, it will have a huge negative effect and seriously affect the overall operation status.

\section{Countermeasures and suggestions on innovating China's rural Internet financial supervision}

Rural Internet finance has the characteristics of Inclusive Finance. Although there are many

risks, we should take corresponding measures to strengthen supervision and management, increase the supply of system, and guide the standardized development of rural Internet finance.

\subsection{Establish and perfect the rural credit system}

The establishment of rural credit reporting system is the basis for the healthy development

of rural Internet finance. We should strengthen the toplevel design, determine the unified standard of rural Internet credit reporting through the people's Bank of China and other financial supervision and management departments, establish the rural credit reporting system, integrate the original and decentralized credit information platform data, and integrate them into the new credit reference system.

\subsection{Improve the rural Internet financial risk prevention mechanism}

Rural Internet finance is the combination of information technology and rural finance. Facing

the rural financial entities with poor risk prevention awareness and prevention and control ability, its operational risk tends to be amplified. First, the government should establish a scientific and effective risk prevention mechanism and risk prevention system by strengthening scientific research projects, increasing capital investment and strengthening policy guidance, so as to reduce the risk of rural Internet financial development. Secondly, it is necessary to clarify the main body and responsibility of rural Internet financial supervision by clarifying the responsibilities, and bring the existing risks into the clear scope of subject responsibility. On this basis, we should strengthen the coordinated action of the rural Internet financial regulatory bodies, carry out joint supervision, share regulatory data, introduce joint regulatory measures, establish strict disciplinary mechanism, improve the social cost of violators, and improve the efficiency and effect of supervision and management. Third, the rural Internet financial operators should strengthen the risk awareness and risk identification ability by strengthening learning and training, improve the prevention level and prevention ability of rural Internet financial business in the process of participation, strengthen internal control and management, and achieve the operation in accordance with laws and regulations, and healthy and sustainable development.

\subsection{Strengthen the foundation of rural Internet Finance Development}

The construction and improvement of infrastructure is the bottom pillar of the development of rural Internet finance. On the one hand, the government should strengthen the construction and improvement of information infrastructure, consolidate the foundation of rural Internet financial development, promote the coordination of online and offline development, so as to reduce operational risk. On the other hand, rural Internet financial operators should strengthen training, enhance staff's awareness and ability of information management risk, strengthen the training and introduction of technical personnel, and reduce information risk and network security risk from service and technology. At the same time, the government and rural Internet financial operators should carry out publicity and education on Internet financial knowledge and security knowledge for financing demanders through various channels, so as to enhance their risk prevention awareness and risk identification ability, and reduce the risk of financing parties.

\subsection{Establish and improve the legal system of rural Internet Finance}

The government should provide good legal support to promote the standardized development of rural Internet Finance by formulating laws that keep pace with the times.

(1) Build a healthy ecological system of rural Internet Finance by law. Through legislation, strictly regulate the access and exit of rural Internet Finance in accordance with the law, limit the risk to the entrance, so that the business entities can be legal and compliant when entering the market. Once illegal, they should be investigated and punished according to law and forced to withdraw, so as to establish a safe and reliable rural Internet financial ecosystem. To strengthen the legal norms, supervision and management of rural Internet financial operation, especially the flow of funds, we should strictly abide by the law and punish those who violate the law.

(2) Implement differentiated supervision measures through legislation. Through the law of rural Internet finance to carry out differentiated supervision and management. In the legislation, we should take different regulatory measures according to the different operation modes and characteristics of rural Internet finance, and support multi-level innovation of rural Internet finance, supplement the legal loopholes of rural Internet financial supervision from the legal level, and finally build a rural Internet financial supervision system that is consistent 
with China's rural financial needs and has the ability to prevent rural interconnection At the same time, it can promote the healthy development of new financial formats.

\section{Reference}

1. Tong Aihua. Development status and Countermeasures of Inclusive Finance in rural China [J]. Jiangsu business theory, 2019 (8): 96-99

2. Meng Qinghai. Development strategy of Internet plus rural finance [J]. sericulture of Guangdong, 2019 (5): 65-66.

3. Kuang Xian Ming. Leveraging the Internet plus reshaping the new pattern of rural finance $[\mathrm{N}]$. China Securities Journal, 2015-07-27:A15.

4. Liu Zhenbin. Gansu finance [J]. Research on the development and supervision path of Internet finance, 2020 (9): 17-19

5. Su Jiajia, Wang Jiannan. Problems and Countermeasures in the development of rural Internet Financial formats $[\mathrm{J}]$. Business economics research, 2020 (6): $164-167$

6. Wang Weiqing, Zhang lezhu, Wang Jiannan. Agricultural economy [J]. China's rural Internet finance business model, development dilemma and coping strategies, 2020 (11): 109-110

7. He Ping Ge, Yi famin. Analysis of rural Internet financial risk and its supervision $[\mathrm{J}]$. Southern rural, 2018 (6): 33-38 